\title{
Students' Static Activities in relation to Campus Quad Design and Layout. Exploring Gender-based Differences
}

\author{
Mahbub Rashid \\ University of Kansas, USA \\ mrashid@ku.edu \\ Bushra Obeidat \\ Jordan University of Science and Technology, Jordan \\ bbobeidat@just.edu.jo
}

\begin{abstract}
This study explores the relationships of campus quad design and layout with students' static activities focusing on gender differences. Students' static activities were observed at 8914 locations during 390 rounds of observation in six campus quads of a Middle Eastern university. The design and layout data of the quads were collected in the field, and using various techniques of "space syntax". The relationships of static activities' with the design and layout features of the quads were investigated using descriptive and correlational statistics. The results of the study indicate that different design and layout features had different relationships with different static activities; that students' static activities had stronger relationships with natural design features than manmade design features; and that male students' and female students' static activities were affected differently by different design and layout features. The significance of these findings and the future directions of research are discussed.
\end{abstract}

Keywords: campus quads, design and layout features, natural and manmade features, gender, static activities, space syntax

To cite this article:

Rashid, M., Obeidat, B. (2020). Students' Static Activities in relation to Campus Quad Design and Layout. Exploring Gender-based Differences, The Journal of Public Space, 5(I), 75-94, DOI $10.3289 \mid / j p s . v 5 i l .1252$

This article has been double blind peer reviewed and accepted for publication in The Journal of Public Space. cc (1) \$ This work is licensed under a Creative Commons Attribution - Non Commercial 4.0 International License https://creativecommons.org/licenses/by-nc/4.0/ 


\section{Introduction}

Most college campuses provide settings for lively small-scale public spaces. Some of these public spaces are well-built campus quads, while others are kept more natural. Despite some similarities, campus quads generally lack the diverse mix of functions, forms, and users that characterize lively urban spaces. Often, campus quads have better physical definition than most urban spaces, but lack the intensity and mix of traffic commonly found in urban spaces. Campus quads are also programmatically more rigid than urban spaces. As a result, environmental behaviors in campus quads and urban spaces may show differences.

Studies involving small-scale urban public spaces are plentiful covering many physical, affective, and behavioral issues (Galindo and Corraliza, 2000, Herzog et al., 2003, Lau et al., 2014, Lo et al., 2003, Shi et al., 2014, Woolley, 2003, Whyte, 1980, Francis, 2003, Stamps, 2005, Stamps and Smith, 2002, Gehl, 20I I). In contrast, studies on campus quads are fewer, and they do not cover as many issues (Abu-Ghazzeh, 1999, Rached and Elsharkawy, 20I2, Salama, 2008, Al-Homoud and Abu-Obeid, 2003, Aydin and Ter, 2008, McFarland et al., 2008, Unlu et al., 2009, Yaylali-Yildiz et al., 20 I4). For example, studies involving public spaces have already shown that women are more sensitive to where they sit in these spaces; and that they tend to seclude themselves in these spaces (Mozingo, 1989, Whyte, 1980). These studies have also shown that in some cultures women experience more controlled than men in public spaces in terms of audience, spatial opportunities, and spatial organization (Abbas and van Heur, 20I4, Al-Bishawi and Ghadban, 20II). However, similar studies on campus quads are missing. In order to fill in the gap, this study focuses on the relationships of various design and layout features of campus quads with students' static activities focusing on male and female differences. Following a brief review of the effects of campus quad design and layout features on behaviors reported in the literature, the conceptual framework and the questions of this study are presented. After this, the study sites and the methods of data collection and analyses are discussed in the methodology section of the paper. Then, the findings of the analyses are reported indicating whether they answer the study questions. In the final section of the paper, the significance of the findings and some future directions of research are discussed.

\section{The Conceptual Model of the Research}

Previous studies already highlight the importance of many design and layout features for students' behaviors in campus spaces. They explore how natural elements affect students' behaviors in campus spaces. For example, the presence of natural elements increases space use (Salama, 2008, Unlu et al., 2009); among various design elements, the effects of landscape on students' distribution in campus public spaces are more significant (Ding and Guaralda, 20I3); campus spaces with less greenery or lawns are used less (Ding and Guaralda, 2013); and campus spaces featuring a natural ground element (e.g., lawns) become popular destinations (Ding and Guaralda, 20I3). They also explore how manmade design and layout features affect students' behaviors in campus spaces. For example, location, accessibility, seating spaces, and visual qualities are important elements affecting students' experience (Abu-Ghazzeh, 1999, Aydin and Ter, 2008, Yaylali-Yildiz et al., 20I4); visually accessible spaces support more student interactions and use of spaces (Unlu et al., 2009); and vertical elements (e.g., walls) have 
more impacts on students' perception on enclosure than horizontal elements (ground or floor) (Al-Homoud and Abu-Obeid, 2003, Abu-Obeid and Al-Homoud, 2000). Additionally, they explore how students' behaviours and perception may affect one another in campus spaces. For example, higher pedestrian volume creates more social interactions (Abu-Ghazzeh, 1999); movements in campus spaces affects how and where students position themselves (Ding and Guaralda, 2013, Greene and Penn, 1997); the perception of seclusion may decrease with increasing pedestrian flow, and may increase with increasing spatial enclosure (Al-Homoud and Abu-Obeid, 2003); the perception of interaction may increase with increasing pedestrian flow (Al-Homoud and Abu-Obeid, 2003); and the vitality of campus spaces may be affected by the location of individual subjects (Al-Homoud and Abu-Obeid, 2003).

Yet, none of these studies explores the relationships of campus quad design and layout with students' static activities focusing on gender differences. Therefore, developed based on the evidence presented here, the conceptual model of this research, presented in Figure I, highlights the significance of gender as an intervening variable for the relationship between environmental design and behaviour in campus quads.

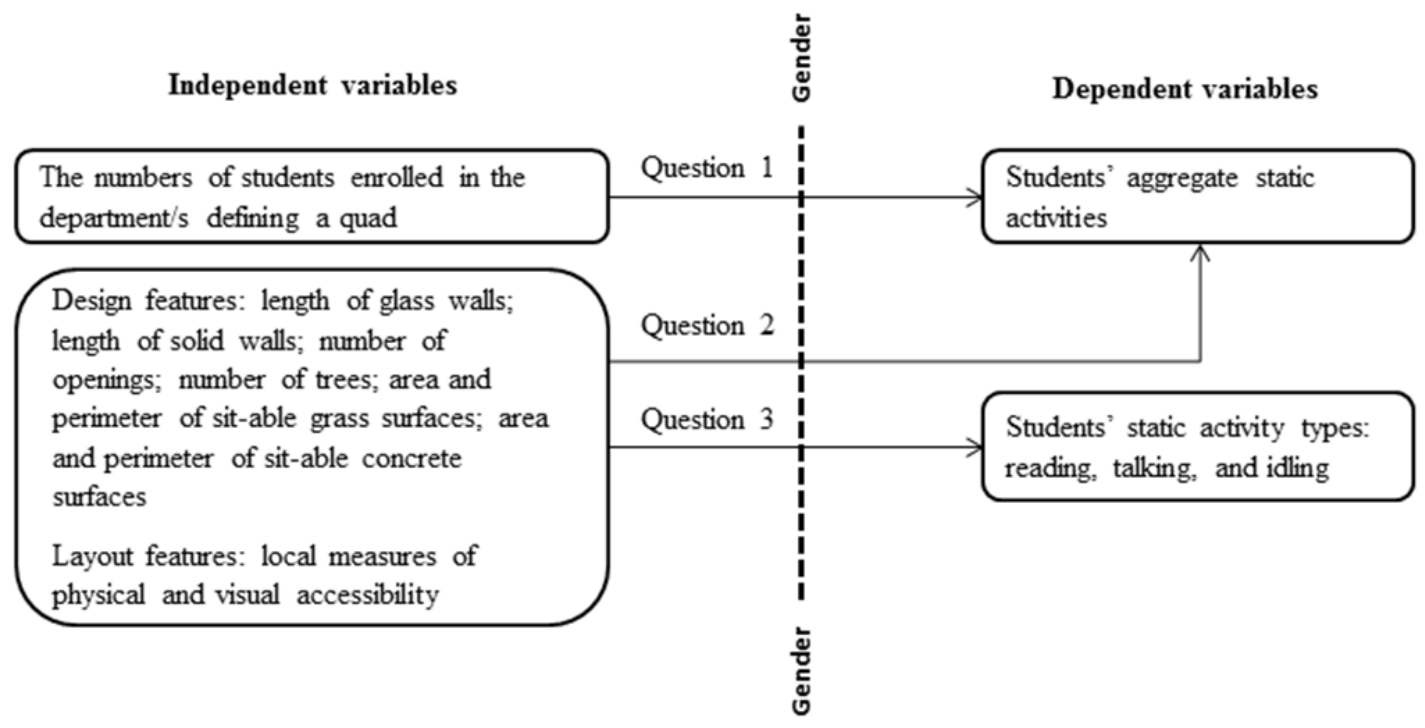

Figure I: The conceptual framework of the study.

The independent variables of the model are the number of students enrolled in the department/s defining a campus quad, and the design and layout features of a campus quad. The manmade and natural design features of a campus quad in the conceptual framework are the length of glass walls; the number of openings on the walls; the length of solid walls; the area and perimeter of sit-able concrete surfaces; the number of trees; and the area and perimeter of sit-able grass surfaces. The layout features in the conceptual framework are the local measures of physical and visual accessibility within campus quads measured using "space syntax" techniques (see below). The dependent variables of the model are students' static activities - reading, talking, and idling. As shown in the model, this study explores the following three questions: 
I. Do the numbers of enrolled students in the department/s defining a campus quad show correlations with students' aggregate static activities in the quad, and do the correlations vary for male and female students?

2. Do different design and layout features of campus quads show correlations with students' aggregate static activities, with natural elements having stronger correlations, and do these correlations vary for male and female students?

3. Do different design and layout features of campus quads show correlations with students' different static activities, with natural elements having stronger correlations, and do these correlations vary for male and female students?

\section{Methodologies}

The study was completed in three phases. In the first phase, data on static activities were collected using pre-established observation protocols in six campus quads. In the second phase, design and layout data were collected on-site and using the spatial analysis techniques of "space syntax". In the third phase, statistical analyses were performed exploring the associations of design and layout data with static activities data. Each of these phases and the study sites are described below.

\section{The Study Sites}

The study was conducted at the Jordan University of Science and Technology in Jordan in the Middle East, because genders are generally divided between public and private spaces in this region (Reininger, 2004). Here, in public spaces, interactions among peers of different sexes are discouraged and interactions among same-sex peers are encouraged. With the exceptions of a few individual communities and family groups, women in Jordan are invisible in public spaces. Social restrictions discourage their participation in social life and define the space to which they belong. Thus, women may be seen interacting more in private spaces and less in public spaces (Ministry of Planning and International Cooperation of the Kingdom of Jordan and United Nations Development Program, 2004).

Six quads of the campus were selected for this study. They have similar size, shape and architecture [Figure 2]. The six campus quads are located in six different departments. We label these departments as $A, B, C, D, E$ and $F$; therefore, the quads within these departments are called A-Quad, B-Quad, C-Quad, D-Quad, E-Quad, and F-Quad. Even though the class schedules of $A, B, C, D, E$, and $F$ departments vary, the amount of time students spend over a day and a week are comparable in these and other departments of this university, as our field investigations indicated. Figure 3.I shows that $A, B, C, D$, $E$, and $F$ departments have different numbers of enrolled students, with A-Department having the highest and C-Department having the lowest number of enrolled students. Figure 3.2 shows the percentages of male and female students in each department. Figures 3.3 and 3.4 show the rank orders of the departments for male and female students' enrollment percentages. For male students, the descending rank order is $F, E$, $B, A, C$, and $D$. For female students, the descending rank is $D, C, A, B, E$, and $F$. 


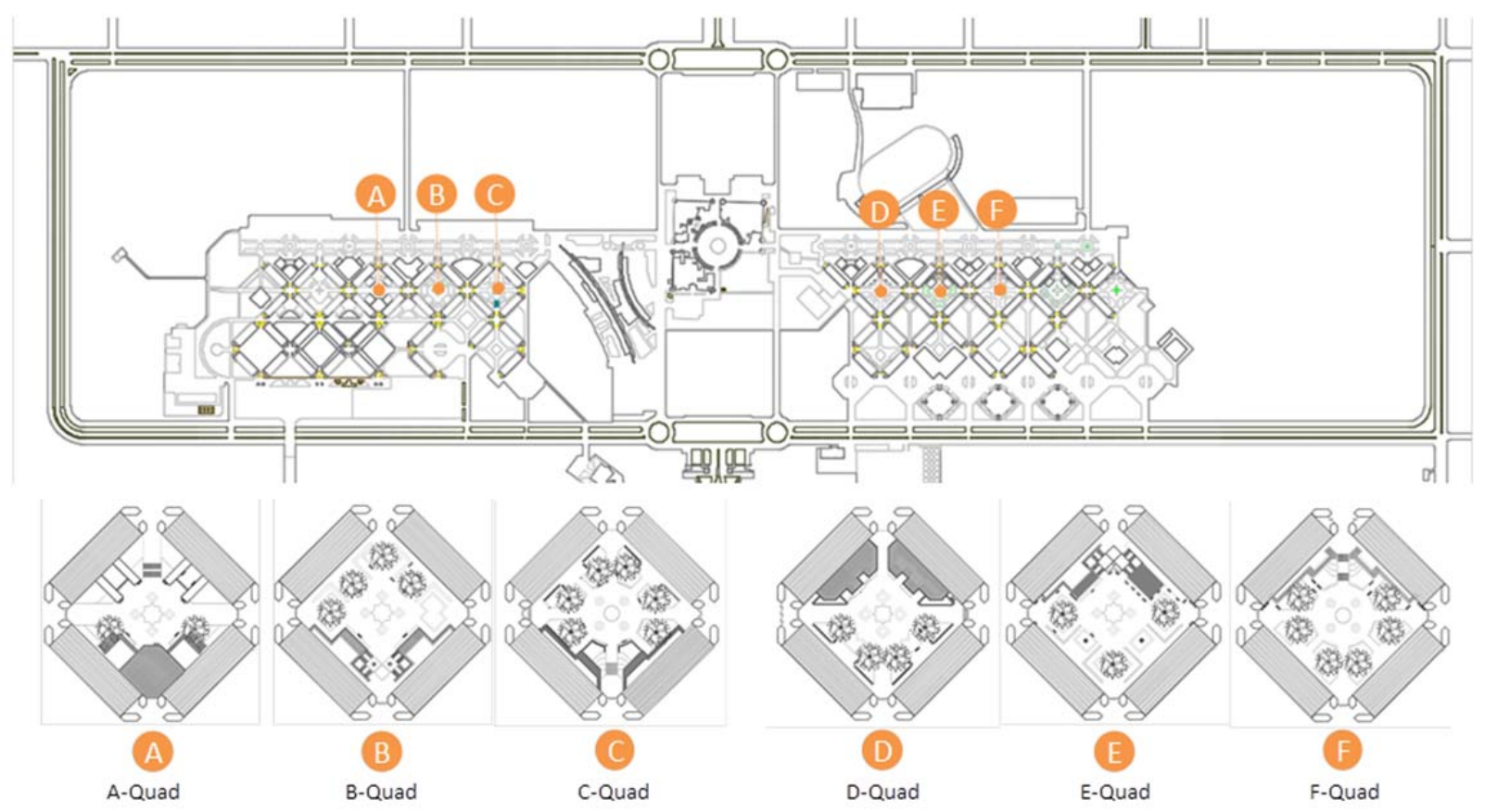

Figure 2: Six quads-A-Quad, B-Quad, C-Quad, D-Quad, E-Quad and F-Quad, and their locations in the university campus.

\section{Collection of Behavioral Data}

One male and one female student of the university were trained to collect behavioral data in the six campus quads. One student was responsible for taking photos and short videos of the quads from a predefined set of positions covering the whole area of each quad. These photos and videos were taken at a regular interval of 30 minutes for five consecutive weekdays from 8:00 am to $2: 00 \mathrm{pm}$. The other student was responsible for recording students (male and female) found engaged in different static activities (reading, talking, and idling) at the same 30-minute interval on the plan of a quad. In the end, the videos and photographs were used to verify the field observations of students' static activities recorded at different locations of a quad. Altogether, 13 rounds of observations were completed in each quad for each of the 5 weekdays. During 390 rounds of observations (65 rounds per quad), the static activities of male and female students at 8,914 locations in the six quads were collected.

\section{Collection of Data on Campus Quad Design and Layout}

Data on the manmade and natural design features of the quads were collected on-site [Table I]. The data show differences among the six quads; therefore, they are expected to have differential effects on students' static activities in these quads, as was stipulated in the conceptual framework. 


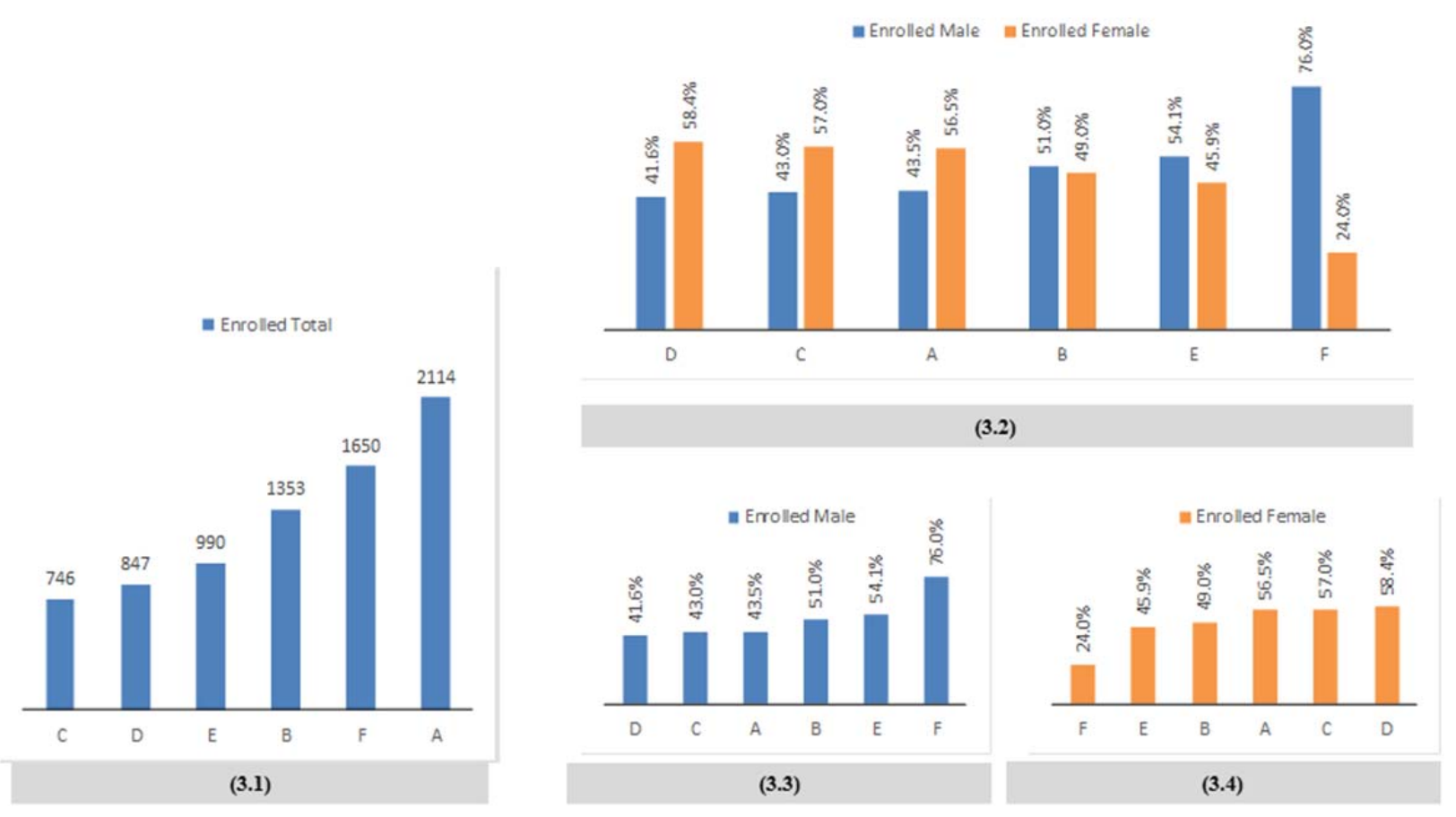

Figure 3: (3.I) The rank-order of departments by the total number of enrolled students, (3.2) the percentages of male and female students enrolled in the six departments at the time of this study, (3.3) the rank-order of departments by the percentages of male students, and (3.4) the rank-order of departments by the percentages of female students.

Measures characterizing the visual and physical accessibility of spaces within a quad were collected using various spatial analysis techniques of "space syntax". These measures showed significant associations with spatial behaviors in buildings and urban environments in previous studies (e.g., Bada and Farhi, 2009, Campos, 1997, Peponis et al., 1997, Rashid et al., 2006, Rashid et al., 2009, Unlu et al., 2009). In order to describe the layout properties of the campus quads, the axial map analysis and the visibility graph analysis (VGA) of space syntax were performed using the Depthmap software, version 10.10.16b (e.g., Turner and Friedrich, 2000-20II).

\begin{tabular}{lllllll}
\hline & $\begin{array}{l}\text { A- } \\
\text { Quad }\end{array}$ & $\begin{array}{l}\text { B- } \\
\text { Quad }\end{array}$ & $\begin{array}{l}\text { C- } \\
\text { Quad }\end{array}$ & $\begin{array}{l}\text { D- } \\
\text { Quad }\end{array}$ & $\begin{array}{l}\text { E- } \\
\text { Quad }\end{array}$ & $\begin{array}{l}\text { F- } \\
\text { Quad }\end{array}$ \\
\hline \multirow{2}{*}{ Length of glass walls } & 120.30 & 136.00 & 136.00 & 168.00 & $\mathrm{II} 8.50$ & $\mathrm{I} 32.00$ \\
& $\mathrm{~m}$ & $\mathrm{~m}$ & $\mathrm{~m}$ & $\mathrm{~m}$ & $\mathrm{~m}$ & $\mathrm{~m}$ \\
\hline Number of openings & 94.00 & $\mathrm{II} 0.00$ & $\mathrm{II} 2.00$ & $\mathrm{I} 20.00$ & 95.00 & $\mathrm{II} 2.00$ \\
\hline \multirow{2}{*}{ Length of solid walls } & $\mathrm{II} 8.80$ & $\mathrm{I} 40.20$ & $\mathrm{I} 20.20$ & $\mathrm{I} 54.02$ & $\mathrm{I} 41.50$ & 103.00 \\
& $\mathrm{~m}$ & $\mathrm{~m}$ & $\mathrm{~m}$ & $\mathrm{~m}$ & $\mathrm{~m}$ & $\mathrm{~m}$ \\
\hline Area of sit-able concrete & $91.43 \mathrm{~m}^{2}$ & 391.10 & $\mathrm{I} 84.44$ & 200.62 & 391.10 & $\mathrm{I} 84.44$ \\
surfaces & & $\mathrm{m}^{2}$ & $\mathrm{~m}^{2}$ & $\mathrm{~m}^{2}$ & $\mathrm{~m}^{2}$ & $\mathrm{~m}^{2}$ \\
\hline Perimeter of sit-able concrete & 548.37 & 870.93 & 769.14 & 839.68 & 870.93 & 769.14 \\
surfaces & $\mathrm{m}$ & $\mathrm{m}$ & $\mathrm{m}$ & $\mathrm{m}$ & $\mathrm{m}$ & $\mathrm{m}$ \\
\hline
\end{tabular}




\begin{tabular}{|c|c|c|c|c|c|c|}
\hline Number of trees & 2 & 4 & 6 & 4 & 3 & 6 \\
\hline \multirow{2}{*}{ Area of sit-able grass surfaces } & $0.00 \mathrm{~m}^{2}$ & 383.17 & 779.75 & 328.53 & 383.17 & 779.75 \\
\hline & & $\mathrm{m}^{2}$ & $\mathrm{~m}^{2}$ & $\mathrm{~m}^{2}$ & $\mathrm{~m}^{2}$ & $\mathrm{~m}^{2}$ \\
\hline $\begin{array}{l}\text { Perimeter of sit-able grass } \\
\text { surfaces }\end{array}$ & $0.00 \mathrm{~m}$ & $\begin{array}{l}224.05 \\
\mathrm{~m}\end{array}$ & $\begin{array}{l}295.78 \\
\mathrm{~m}\end{array}$ & $\begin{array}{l}161.64 \\
\mathrm{~m}\end{array}$ & $\begin{array}{l}224.05 \\
\mathrm{~m}\end{array}$ & $\begin{array}{l}295.78 \\
\mathrm{~m}\end{array}$ \\
\hline
\end{tabular}

Table I: Various design features of the quads

For the axial map analysis, the layout of a campus quad was reduced to a fewest set of axial lines covering all routes of movements and circulation rings. Syntactic measures describing physical and visual accessibility were then computed based on how the lines were connected to each other in the map (Hillier and Hanson, 1984). For this study, local instead of global syntactic measures were used, because static activities are likely to be affected more by local than global factors. These measures are local axial integration at radius 3 describing how a line is connected to the lines 3 steps away from it, and axial connectivity describing how many lines are directly connected to a line. For VGA, the campus quads were divided into a cellular grid with cells sufficiently large to accommodate a person. Syntactic measures describing physical and visual accessibility were then computed based on how the visual fields of the cells in the grid are connected to each other (Turner et al., 200 I). Again, two local measures were used: local visual integration at radius 3 and visual connectivity.

For the purpose of this study, the local integration and connectivity values were computed at three different heights describing physical and/or visual access to different amounts of information in the quads. In other words, local axial integration, axial connectivity, local visual integration, and visual connectivity at $0.0 \mathrm{~m}\left(0^{\prime}\right)$ level were used describing physical and visual accessibility at the ground level, where the amount of information available was very limited. Local axial integration, axial connectivity, local visual integration, \& visual connectivity at $1.10 \mathrm{~m}$ (3'6") above the ground were used describing physical and visual accessibility for seated students, where the amount of information available was somewhat limited. Finally, local axial integration, axial connectivity, local visual integration, \& visual connectivity at $1.65 \mathrm{~m}$ (5'5") above the ground were used describing physical and visual accessibility for standing students, where the amount of information available was least limited.

\section{Statistical Analysis}

Using IBM SPSS 22 (IBM, 20I3), statistical analyses were performed to describe the similarities and differences in students' static activities in the six quads, and to describe the relationships between design and layout variables and students' static activities.

- To answer Q-I, histograms and descriptive statistics were used to study the relationships between students' static activities and departmental enrollment numbers.

- To answer Q-2, correlational statistics were used to study the relationships between the aggregate numbers of students' activities and campus quads' design and layout variables. It is important to note here that, for correlational analysis, 
each quad was divided into four quadrants, and observations made in a quadrant were aggregated and associated with the measures of the design and layout features of the quadrant. Therefore, data from the 24 quadrants $(n=24)$ of the six quads were used in correlational analysis.

- To answer Q-3, correlational statistics were used to study the relationships between students' different static activities and campus quads' design and layout variables. Again, data from the 24 quadrants $(n=24)$ of the six quads were used for correlational analysis.

The above analyses were performed for all students, male students, and female students. Following Evans' (1996) interpretation of Pearson's correlation coefficient, the following estimates were used to interpret Spearman's correlation coefficient $(\rho): .00-.19$ as "very weak"; .20-.39 as "weak"; .40-.59 as "moderate"; .60-.79 as "strong"; and .80-I.0 as "very strong".

\section{Results}

\section{Students' static Activities and departmental enrolments}

\section{All students' static activities and departmental enrolments}

All students' static activities [Figure 4] were not consistent with the enrollment numbers of the departments presented earlier [Figure 3]. The descending rank order of the departments for enrolment was A, F, B, E, D, and C. In contrast, the descending rank order of the departments for talking among all students was $C, F, D, A, B$, and $E$. The descending rank order of the departments for reading among all students was $C, F$, $B, A, D$, and $E$. Finally, the descending rank order of the departments for idling among all students was A, D, F, C, B, and E. Therefore, higher enrolments did not consistently produce higher aggregate numbers of static activities among students in these quads.

\section{Male and female students' static activities and departmental enrolments}

Like all students' activities, the percentages of male students' and female students' static activities [Figure 5] in the quads did not consistently follow the percentages of enrolled male students and female students in the departments presented earlier [Figure 3].

The descending rank order of the departments for male students' enrolment was F, E, $B, A, C$, and $D$. In contrast, the descending rank order for talking among male students was $A, D, E, F, C$, and $B$. The descending rank order for reading among male students was $A, D, F, E, C$, and B. Finally, the descending rank order for idling among male students was $E, A, B, D, C$, and $F$.

The descending rank order of the departments for female students' enrolment was $D$, $C, A, B, E$, and $F$. In contrast, the descending rank order for talking among female students was $B, C, F, E, D$, and $A$. The descending rank order for reading among female students was $B, C, E, F, D$, and $A$. Finally, the descending rank order for idling among female students was F, C, D, B, A, and E.

In summary, the rank order of departments based on the enrolment numbers of male students and female students were not consistent with the rank order of department based on static activities among male students or female students in these quads. 


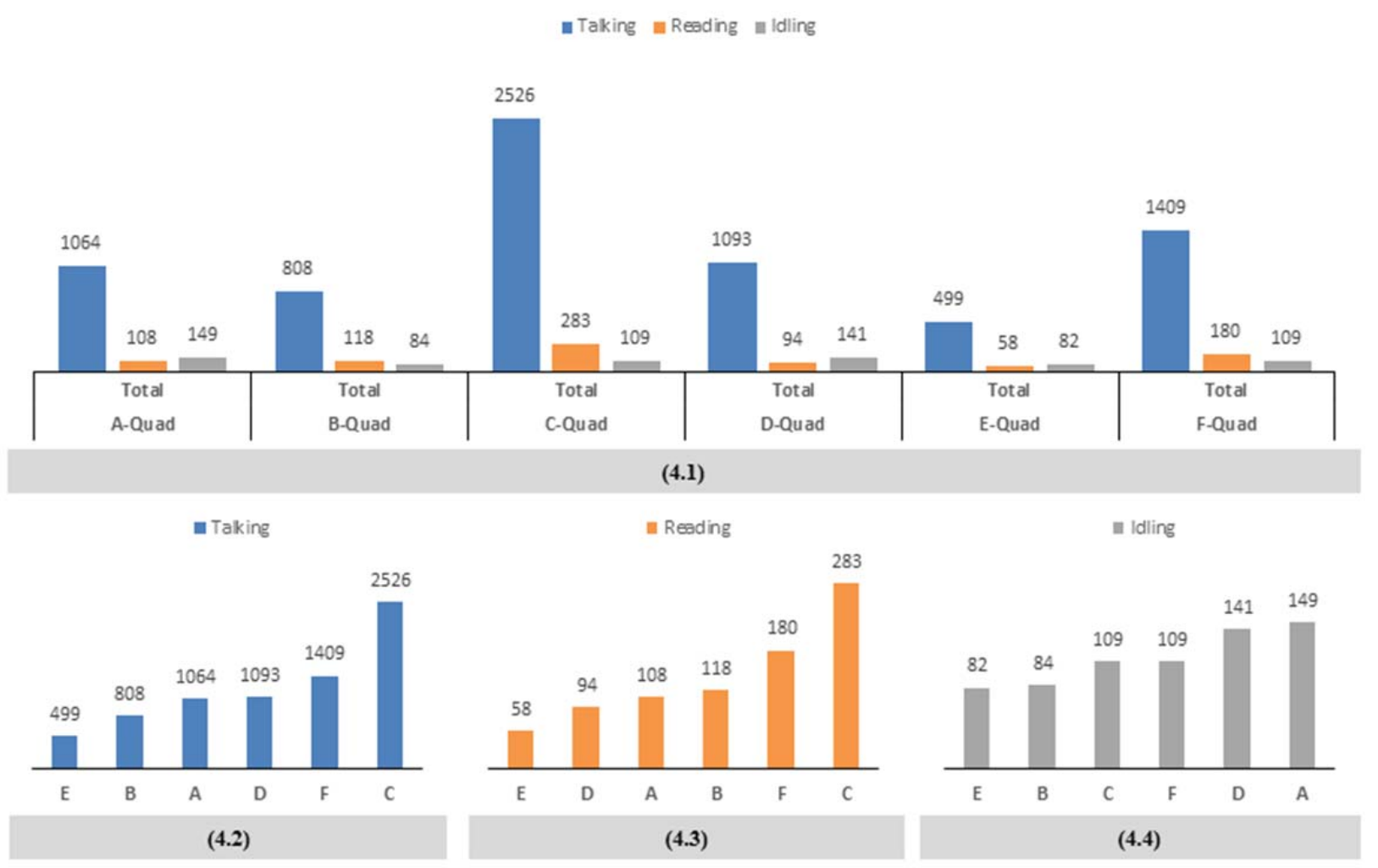

Figure 4: (4.I) The total numbers of static activities observed in the six quads at the time of this study, (4.2) the rank-order of the total number of students engaged in talking activity, (4.3) the rank-order of the total number of students engaged in reading activity, and (4.4) the rank-order of the total number of idling students.

\section{Students' aggregate static activities and campus quad design and layout Students' aggregate static activities and campus quad design [Table 2]}

According to the correlational analysis, the length of glass walls shows somewhat significant moderate positive correlations with male students' and all students' aggregate activities $\left(.449 *\right.$ and $\left..410^{*}\right)$, and a non-significant weak positive correlation with female students' aggregate activities. The number of openings shows a somewhat significant moderate positive correlation with male students' aggregate activities (.439*), and nonsignificant weak positive correlations with all students' and female students' aggregate activities. The length of solid walls shows somewhat significant and significant moderate negative correlations with all students', male students' and female students' aggregate activities $\left(-.492^{*},-.533^{* *}\right.$, and $\left.-.405^{*}\right)$. The area and perimeter of sit-able concrete surfaces show non-significant very weak to weak positive correlations with all students', male students', and female students' aggregate activities.

The number of trees shows somewhat significant and significant moderate to strong positive correlations with all students', male students', and female students' aggregate activities $\left(.620^{* *}, .476^{*}\right.$, and $\left..726^{* *}\right)$. The area and perimeter of sit-able grass surfaces show somewhat significant and significant moderate positive correlations with all students' and female students' aggregate activities (all students: .459* and .409*; female students: .559** and .519**), and a non-significant weak positive correlation with male students' aggregate activities. 
Therefore, some manmade and natural design features show significant correlations of different strengths with students' static activities. In general, natural features show stronger correlations with students' static activities than manmade design features. Many of these correlations are stronger for female students' than male students' activities. Male students' and female students' static activities are also correlated with different campus quad design features, with male students' activities correlated more frequently with the artificial features, and female students' activities correlated more frequently with the natural features.

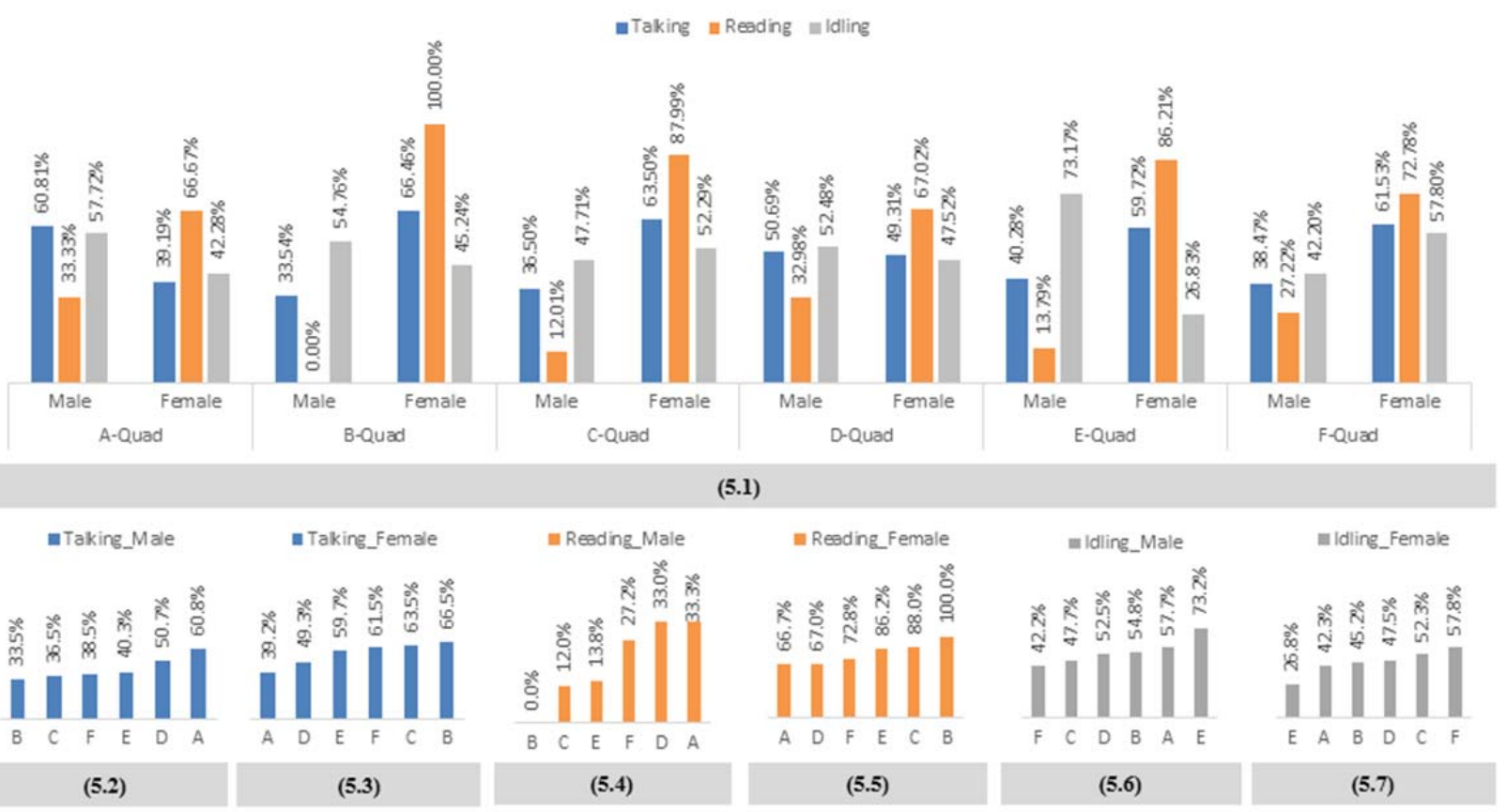

Figure 5: (5. I) Percentages of male and female students engaged in different static activities in the six quads, (5.2) the rank-order of percentages of male students engaged in talking activity, (5.3) the rank-order of percentages of

female students engaged in talking activity, (5.4) the rank-order of percentages of male students engaged in reading activity, (5.5) the rank-order of percentages of female students engaged in reading activity, (5.6) the rankorder of percentages of idling male students, and (5.7) the rank-order of percentages of idling female students.

\begin{tabular}{llll}
\hline & \multicolumn{3}{l}{ Students' aggregate activities } \\
\hline Natural and artificial design elements & $\mathrm{AS}^{\prime}$ & $\mathrm{MS}^{\prime}$ & $\mathrm{FS}^{\prime}$ \\
\hline Length of glass walls & $.410^{*}$ & $.449^{*}$ & .310 \\
\hline Number of openings & .394 & $.439^{*}$ & .300 \\
\hline Length of solid walls & $-.492^{*}$ & $-.533^{* *}$ & $-.405^{*}$ \\
\hline Area of sit-able concrete surfaces & .145 & .049 & .214 \\
\hline Perimeter of sit-able concrete surfaces & .338 & .341 & .275 \\
\hline Number of trees & $.620^{* *}$ & $.476^{*}$ & $.726^{* *}$ \\
\hline Area of sit-able grass surfaces & $.459^{*}$ & .329 & $.559^{* *}$ \\
\hline Perimeter of sit-able grass surfaces & $.409^{*}$ & .264 & $.519 * *$ \\
\hline
\end{tabular}




\begin{tabular}{|c|c|c|c|}
\hline \multicolumn{4}{|c|}{ Physical and visual accessibility in quad layouts } \\
\hline Local Axial Integration at $0.0 \mathrm{~m}$ Level & .311 & .324 & .210 \\
\hline Axial Connectivity at $0.0 \mathrm{~m}$ Level & .113 & -.070 & .217 \\
\hline Local Axial Integration at $1.10 \mathrm{~m}$ Level & .178 & -.057 & .351 \\
\hline Axial Connectivity at $1.10 \mathrm{~m}$ Level & -.035 & -.175 & .089 \\
\hline Local Axial Integration at $1.65 \mathrm{~m}$ Level & .247 & -.019 & $.466^{*}$ \\
\hline Axial Connectivity at $1.65 \mathrm{~m}$ Level & .353 & .153 & $.539 * *$ \\
\hline Local Visual Integration at $0.0 \mathrm{~m}$ Level & $.439 *$ & $.548 * *$ & .327 \\
\hline Visual Connectivity at $0.0 \mathrm{~m}$ Level & -.002 & .231 & -.157 \\
\hline Local Visual Integration at $1.10 \mathrm{~m}$ Level & $.420 *$ & .336 & $.501 *$ \\
\hline Visual Connectivity at $1.10 \mathrm{~m}$ Level & .194 & .065 & .354 \\
\hline Local Visual Integration at $1.65 \mathrm{~m}$ Level & $.50 I^{*}$ & .281 & $.646 * *$ \\
\hline Visual Connectivity at $1.65 \mathrm{~m}$ Level & .389 & .164 & $.552 * *$ \\
\hline
\end{tabular}

** Significant at the $.0 \mathrm{I}$ level; *Significant at the .05 level; I: AS = All Students; MS = Male Students; FS = Female Students

Table 2: Correlations between students' aggregate activities and campus quad design and layout features $(n=24)$

\section{Students' aggregate static activities and campus quad layout [Table 2]}

Local axial integration and axial connectivity at $0.00 \mathrm{~m}$ and $1.10 \mathrm{~m}$ levels show non-significant weak correlations with all students', male students', and female students' aggregate static activities in the quads. Local axial integration and axial connectivity at $1.65 \mathrm{~m}$ level show somewhat significant and significant moderate positive correlations with female students' aggregate activities (.466* and .539**), and non-significant weak and very weak correlations with all students' and male students' aggregate activities.

Local visual integration at $0.0 \mathrm{~m}$ level shows somewhat significant and significant moderate positive correlations with all students' and male students' aggregate activities (.439* and $.548 * *)$, and a non-significant weak positive correlation with female students' aggregate activities. Visual connectivity at $0.0 \mathrm{~m}$ level shows non-significant very weak correlations with all students', male students', and female students' aggregate activities.

Local visual integration at $1.10 \mathrm{~m}$ level shows somewhat significant moderate positive correlations with all students' and female students' aggregate activities (.420* and $.50 \mathrm{I} *)$, and a non-significant weak positive correlation with male students' aggregate activities. Visual connectivity at $1.10 \mathrm{~m}$ level shows non-significant weak to very weak correlations with all students', male students', and female students' aggregate activities.

Local visual integration at $1.65 \mathrm{~m}$ level shows a somewhat significant moderate positive correlation with all students' aggregate activities $(.50 \mathrm{I})$, a significant strong positive correlation with female students' aggregate activities (646**), and a non-significant weak positive correlation with male students' aggregate activities. Visual connectivity at $1.65 \mathrm{~m}$ level shows non-significant weak and very weak positive correlations with all students' and male students' aggregate activities, and a significant moderate positive correlation with female students' aggregate activities (.552**). 
Therefore, some layout features show significant correlations of different strengths with students' aggregate static activities. Correlations are different for male students' and female students' aggregate activities. The number of correlations of layout features is higher with female students' aggregate activities than with male students' aggregate activities.

\section{Static activities and campus quad design and layout Static activities and campus quad design [Table 3] Talking}

The length of glass walls shows a somewhat significant moderate positive correlation with talking as an activity for male students (.428*); and non-significant weak positive correlations with talking for all students and female students. The number of openings shows non-significant weak to moderate positive correlations with talking for all students, male students, and female students. The length of solid walls shows somewhat significant moderate negative correlations with talking for all students and male students (-.465* and -.476*); and a non-significant weak negative correlation with talking for female students. The area and perimeter of sit-able concrete surfaces show non-significant very weak to weak positive correlations with talking for all students, male students, and female students.

The number of trees shows somewhat significant and significant moderate to strong positive correlations with talking for all students, male students, and female students $\left(.596^{* *}, .453^{*}\right.$, and $\left..710 * *\right)$. The area of grass surfaces shows somewhat significant and significant moderate correlations with talking for all students and female students $\left(.438^{*}\right.$ and $\left..558^{* *}\right)$, and a non-significant weak correlation with talking for male students. The perimeter of grass surfaces shows non-significant weak correlations with talking for all students and male students; and a significant moderate correlation for female students $\left(.515^{* *}\right)$.

Therefore, some manmade and natural design features show significant correlations of different strengths with talking among students. Talking shows stronger correlations with the natural features than it does with the manmade design features. The natural features have several significant strong correlations with talking among female students, but only one non-significant weak correlation with talking among male students.

\begin{tabular}{lccccccccc}
\hline & \multicolumn{3}{c}{ Talking } & \multicolumn{3}{c}{ Reading } & \multicolumn{3}{c}{ Idling } \\
\hline $\begin{array}{l}\text { Natural and artificial design } \\
\text { elements }\end{array}$ & $\mathrm{AS}^{\prime}$ & $\mathrm{MS}^{\prime}$ & $\mathrm{FS}^{\prime}$ & $\mathrm{AS}^{\prime}$ & $\mathrm{MS}^{\prime}$ & $\mathrm{FS}^{\prime}$ & $\mathrm{AS}^{\prime}$ & $\mathrm{MS}^{\prime}$ & $\mathrm{FS}^{\prime}$ \\
\hline Length of glass walls & .385 & $.428^{*}$ & .289 & .354 & .180 & .310 & $.566^{* *}$ & $.616^{* *}$ & $.470^{*}$ \\
\hline Number of openings & .366 & .400 & .286 & .279 & .249 & .225 & $.58 I^{* *}$ & $.673^{* *}$ & $.497^{*}$ \\
\hline Length of solid walls & $-.465^{*}$ & $-.476^{*}$ & -.398 & -.254 & -.359 & -.151 & - & - & - \\
\hline $\begin{array}{l}\text { Area of sit-able concrete } \\
\text { surfaces }\end{array}$ & .119 & .033 & .209 & .073 & -.249 & .091 & .267 & .380 & .264 \\
\hline $\begin{array}{l}\text { Perimeter of sit-able concrete } \\
\text { surfaces }\end{array}$ & .312 & .314 & .254 & .234 & .044 & .195 & $.530^{* * *}$ & $.677^{* *}$ & $.424^{*}$ \\
\hline
\end{tabular}




\begin{tabular}{|c|c|c|c|c|c|c|c|c|c|}
\hline Number of trees & $.596 * *$ & $.453^{*}$ & $.710 * *$ & $.547 * *$ & .299 & $.524 * *$ & $.524 * *$ & $.428 *$ & $.663^{* *}$ \\
\hline Area of sit-able grass surfaces & $.438 *$ & .299 & $.558 * *$ & .380 & .238 & .363 & .360 & .340 & $.486 *$ \\
\hline $\begin{array}{l}\text { Perimeter of sit-able grass } \\
\text { surfaces }\end{array}$ & .387 & .242 & $.515^{* *}$ & .359 & .148 & .357 & .314 & .312 & $.422^{*}$ \\
\hline \multicolumn{10}{|l|}{$\begin{array}{l}\text { Physical and visual } \\
\text { accessibility in quad layouts }\end{array}$} \\
\hline $\begin{array}{l}\text { Local Axial Integration at } 0.0 \mathrm{~m} \\
\text { Level }\end{array}$ & .320 & .322 & .212 & .155 & .017 & $.14 \mid$ & $.410 *$ & .383 & .226 \\
\hline Axial Connectivity at $0.0 \mathrm{~m}$ Level & .115 & -.063 & .243 & .046 & -.306 & .156 & .049 & .169 & -.049 \\
\hline $\begin{array}{l}\text { Local Axial Integration at } 1.10 \mathrm{~m} \\
\text { Level }\end{array}$ & .192 & -.024 & .370 & .250 & -.121 & .310 & -.137 & -.205 & .059 \\
\hline $\begin{array}{l}\text { Axial Connectivity at I.10m } \\
\text { Level }\end{array}$ & -.044 & $-.17 \mid$ & .107 & -.021 &.$-|2|$ & .029 & -.144 & -.089 & -.005 \\
\hline $\begin{array}{l}\text { Local Axial Integration at } 1.65 \mathrm{~m} \\
\text { Level }\end{array}$ & .257 & -.004 & $.482 *$ & .350 & .094 & .402 & -.158 & -.227 & .063 \\
\hline $\begin{array}{l}\text { Axial Connectivity at } 1.65 \mathrm{~m} \\
\text { Level }\end{array}$ & .343 & .160 & $.538^{* *}$ & $.424^{*}$ & .202 & $.43 I^{*}$ & -.009 & -.107 & .277 \\
\hline $\begin{array}{l}\text { Local Visual Integration at } 0.0 \mathrm{~m} \\
\text { Level }\end{array}$ & $.436 *$ & $.512^{*}$ & .309 & .355 & $.748 * *$ & .227 & $.419 *$ & .251 & $.526^{* *}$ \\
\hline $\begin{array}{l}\text { Visual Connectivity at } 0.0 \mathrm{~m} \\
\text { Level }\end{array}$ & -.014 & .208 & -.193 & -.031 & .327 & -.148 & .261 & .134 & .308 \\
\hline $\begin{array}{l}\text { Local Visual Integration at I.I0 } \\
\mathrm{m} \text { Level }\end{array}$ & $.432 *$ & .309 & $.518 * *$ & .386 & $.710 * *$ & .336 & .064 & -.118 & .302 \\
\hline $\begin{array}{l}\text { Visual Connectivity at } 1.10 \mathrm{~m} \\
\text { Level }\end{array}$ & .207 & .053 & .385 & .192 & $.429 *$ & .206 & -.235 & $-.34 I$ & .063 \\
\hline $\begin{array}{l}\text { Local Visual Integration at } 1.65 \mathrm{~m} \\
\text { Level }\end{array}$ & $.505^{*}$ & .283 & $.657^{* *}$ & $.456^{*}$ & .315 & $.449 *$ & .110 & .032 & .332 \\
\hline $\begin{array}{l}\text { Visual Connectivity at } 1.65 \mathrm{~m} \\
\text { Level }\end{array}$ & .396 & .157 & $.57 I^{* *}$ & .367 & .268 & .374 & -.010 & -.020 & .196 \\
\hline
\end{tabular}

** Significant at the .01 level; *Significant at the .05 level; I: AS = All Students; MS = Male Students; FS = Female Students

Table 3: Correlations between students' activities and design features $(n=24)$

\section{Reading}

The length of glass walls shows non-significant very weak to weak positive correlations with reading among all students, male students, and female students. The number of openings shows non-significant weak positive correlations with reading among all students, male students, and female students. The length of solid walls shows nonsignificant very weak to weak negative correlations with reading among all students, male students, and female students. The area and perimeter of sit-able concrete surfaces show non-significant very weak to weak correlations with reading among all students, male students, and female students.

The number of trees shows significant moderate correlations with reading among all students and female students (.547** and $\left..524^{* *}\right)$, and a non-significant weak correlation 
among male students. The area and perimeter of grass surfaces show non-significant very weak to weak positive correlations among all students, male students, and female students.

In sum, among all the natural and artificial design features, the number of trees is the only feature that shows significant strong correlations with reading in these quads.

Idling

The length of glass walls shows somewhat significant and significant moderate to strong positive correlations with idling among all students, male students, and female students (566**, .616**, and.470*). The number of openings shows somewhat significant and significant moderate to strong positive correlations with idling among all students, male students, and female students (.58I** $.673^{* *}$, and.497*). The length of solid walls shows significant strong negative correlations with idling among all students, male students, and female students $\left(-70 \mathrm{I}^{* *},-.750^{* *},-.692^{* *}\right)$. The area of sit-able concrete surfaces shows non-significant weak correlations with idling among all students, male students, and female students. The perimeter of sit-able concrete surfaces shows somewhat significant and significant moderate to strong positive correlations with idling among all students, male students, and female students (.530**, .677**, and .424*).

The number of trees shows somewhat significant and significant moderate to strong positive correlations with idling among all students, male students, and female students $\left(.524^{* *}, .428^{*}\right.$, and $\left..663^{* *}\right)$. The area and perimeter of grass surfaces show non-significant weak positive correlations with idling among all students and male students, but somewhat significant moderate positive correlations with idling among female students (.486* and .422*).

Again, supporting our previous findings, some manmade and natural design features show significant correlations of different strengths with idling. However, idling does not always show stronger correlations with the natural features than the manmade design features, even though the number of trees still shows significant correlations with idling. Again, campus quad design features and idling among male students and female students show different correlations, with female students showing more frequent correlations than male students.

\section{Static activities and campus quad layout [Table 3] \\ Talking}

Local axial integration at $0.00 \mathrm{~m}$ level and axial connectivity at $0.00 \mathrm{~m}$ level show nonsignificant weak correlations with talking among all students, male students, and female students. local axial integration at $1.10 \mathrm{~m}$ level and axial connectivity at $1.10 \mathrm{~m}$ level show non-significant correlations with talking among all students, male students, and female students.

Local axial integration at $1.65 \mathrm{~m}$ level shows a somewhat significant moderate positive correlation with talking among female students $(.482 *)$, but it shows non-significant very weak to weak correlations with talking among all students and male students. Axial connectivity at $1.65 \mathrm{~m}$ level shows a significant moderate positive correlation with talking among female students $\left(.538^{* *}\right)$, but it shows non-significant very weak to weak positive correlations with talking among all students and male students. 
Local visual integration at $0.0 \mathrm{~m}$ level shows somewhat significant moderate positive correlations with talking among all students and male students $\left(.436^{*}\right.$ and $\left..512^{*}\right)$, but it shows a non-significant weak positive correlation with talking among female students. Visual connectivity at $0.0 \mathrm{~m}$ level shows non-significant very weak negative correlations with talking among all students, male students and female students.

Local visual integration at $1.10 \mathrm{~m}$ level shows somewhat significant and significant moderate correlations with talking among all students and female students (.432* and .518**), and a non-significant positive correlation with talking among male students. Visual connectivity at $1.10 \mathrm{~m}$ level shows non-significant very weak to weak correlations with talking among all students, male students and female students.

Local visual integration at $1.65 \mathrm{~m}$ level shows a somewhat significant moderate positive correlation with talking among all students $\left(.505^{*}\right)$, a non-significant very weak correlation with talking among male students, and a significant strong positive correlation with talking among female students (.657**). Visual connectivity at $1.65 \mathrm{~m}$ level shows non-significant very weak correlations with talking among all students and male students, but a significant moderate positive correlation with talking among female students $\left(.57 I^{* *}\right)$.

Therefore, some layout features show significant correlations of different strengths with talking. Among these features, local visual integration at different levels shows better correlations with talking than the other layout variables. In many cases, local axial integration, axial connectivity, local visual integration, and visual connectivity have better correlations with talking among female students than they have with talking among male students.

\section{Reading}

Local axial integration at $0.0 \mathrm{~m}$ and $1.10 \mathrm{~m}$ levels and axial connectivity at $0.0 \mathrm{~m}$ and $1.10 \mathrm{~m}$ levels show non-significant weak to very weak correlations with reading among all students, male students, and female students.

Local axial integration at $1.65 \mathrm{~m}$ level shows non-significant very weak to weak correlations with reading among all students, male students, and female students. Axial connectivity at $1.65 \mathrm{~m}$ level shows somewhat significant moderate positive correlations with reading among all students and female students (.424* and .43।*), and a non-significant weak positive correlation with reading among male students.

Local visual integration at $0.00 \mathrm{~m}$ level shows a significant strong positive correlation with reading among male students $(.748 * *)$, and non-significant weak positive correlations with reading among all students and female students. Visual connectivity at $0.00 \mathrm{~m}$ level shows non-significant very weak to weak negative correlations with reading among all students, male students, and female students.

Local visual integration at $1.10 \mathrm{~m}$ level shows non-significant weak positive correlations with reading among all students and female students, and a significant strong positive 
correlation with reading among male students $\left(.710^{* *}\right)$. Visual connectivity at $1.10 \mathrm{~m}$ level shows non-significant weak to very weak correlations with reading among all students and female students, and a somewhat significant moderate positive correlation with reading among male students $(.429 *)$.

Local visual integration at $1.65 \mathrm{~m}$ level shows somewhat significant moderate positive correlations with reading among all students and female students $\left(.456^{*}\right.$ and $\left..449 *\right)$, and a non-significant weak positive correlation with reading among male students. Visual connectivity at $1.65 \mathrm{~m}$ level shows non-significant weak positive correlations with reading among all students, male students, and female students.

Again, some layout features show significant correlations of different strengths with reading. In general, the layout features showing better correlations with reading among male students are different from those showing better correlations with reading among female students. Local visual integration at $0.00 \mathrm{~m}$ and $1.10 \mathrm{~m}$ levels show significant strong positive correlations with reading among male students.

Idling

Local axial integration at $0.00 \mathrm{~m}$ level shows a significant moderate positive correlation with idling among all students $(.410 *)$; but non-significant weak correlations with idling among male students and female students, separately. Axial connectivity at $0.00 \mathrm{~m}$ level shows non-significant weak correlations with idling among all students, male students, and female students.

Local axial integration and axial connectivity at $1.10 \mathrm{~m}$ and $1.65 \mathrm{~m}$ levels show non-significant very weak to weak correlations with idling among all students, male students and female students.

Local visual integration at $0.00 \mathrm{~m}$ level shows somewhat significant and significant moderate positive correlations with idling among all students and female students (.419* and $.526 * *)$; and a non-significant weak positive correlation with idling among male students. Visual connectivity at $0.00 \mathrm{~m}$ level shows non-significant weak to very weak positive correlations with idling among all students, male students and female students.

Local visual integration and visual connectivity at $1.10 \mathrm{~m}$ and $1.65 \mathrm{~m}$ levels show nonsignificant weak to very weak correlations with idling among all students, male students, and female students.

In summary, only some layout features show significant correlations of different strengths with idling.

\section{Discussion and Conclusions}

According to the results of the study, the total enrolment number as well as the male and female enrolment numbers of a department did not show any consistent relationships with students' static activities in the department's quad.

The study, however, indicated that different campus quad design and layout features had correlations of different strengths with students' static activities; that students' static 
activities often had stronger correlations with the natural design features than the manmade design features; that male and female students static activities were often correlated differently with different design and layout features; and that the natural features and the layout features often had stronger correlations with female students' than male students' static activities.

Among the more interesting findings reported here are that students' aggregate activities, as well as talking and idling separately, decreased as the lengths of solid walls around the quads increased, and that students' idling increased as the number of openings and the length of glass walls around the quads increased. It may be that solid walls do not provide visual access to information; hence, they are less interesting for those engaged in talking and idling. Likewise, openings and glass walls provide visual access to information; hence, they are more interesting for those idling in the quads but less so for those talking in the quads. These findings are in line with the studies that show visual access to information is important for people to decide where to sit in public spaces (Bada and Farhi, 2009, Campos, 1997, Ding and Guaralda, 2013).

As this study showed, visual access to information as well as the amount of visually accessible information, both are important for students' static activities in campus quads. In this study, the local axial integration values at the $0.00 \mathrm{~m}$ and $1.10 \mathrm{~m}$ levels describing access to relatively less information showed very little associations with students' static activities. In contrast, the local axial integration value at the $1.65 \mathrm{~m}$ level describing access to relatively more information showed a few significant associations with students' static activities. Further supporting this claim, the local visual integration values at the $0.00 \mathrm{~m}, 1.10 \mathrm{~m}$, and $1.65 \mathrm{~m}$ levels describing visual access to relatively more information showed several relatively strong associations with students' static activities. These findings are in line with the studies that associate too little information with a lack of interest (Shi et al., 20I4, Unlu et al., 2009, Unlu et al., 200I).

According to this study, students' static activities had stronger positive associations with the natural design features, such as trees and grass surfaces, than the manmade design features, such as solid and glass walls, openings, and concrete surfaces. These findings support human's persistent fascination with nature (Kaplan and Kaplan, 1989, Ulrich, 1986), and the importance of nature in urban spaces in hot-arid climate (Aljawabra and Nikolopoulou, 2010, Rached and Elsharkawy, 20I2). These findings also support the studies that show nature as an important component of urban spaces (Ghavampour et al., 20I5, Herzog et al., 2003) and of campus public spaces (Ding and Guaralda, 2013, Lau et al., 20I4, McFarland et al., 2008, Salama, 2008).

Regarding gender-based differences, the study showed that female students' activities generally had better associations with campus quads' design and layout features than male students' activities had, indicating that female students might have chosen their activity locations more carefully than male students relative to the design and layout features of the quads. More specifically, the study showed that female students' activity locations had better visual access to information than male students' activity locations had. The study also showed that male students' static activities had better associations with the artificial design features such as glass walls, openings, and solid walls; and female students' static activities had better associations with the natural features such as trees and grass surfaces. These findings therefore identify the design and layout features of campus quads as a natural mechanism for gender-based separation in public spaces. 
There are several implications of our findings for campus quad design and use. First, of course, is that student numbers may not be related to how a quad is used for static activities by students. According to our study, this may be in part due to the design and layout features of a quad. For example, natural features like trees are something that may encourage static activities more than many other design and layout features. Access to visual information may be yet another feature one may wish to consider regarding static activities in campus quads. Differences between male and female students' activities in relation to different design features may be important as well for campus quad design. According to findings of this study, it may be possible to increase one kind of static activity in favour of another kind using campus quad design and layout. To conclude, it is necessary to note that future studies should replicate this study in different countries and cultures to improve generalizability of the findings reported here. They should also focus on the effects of campus quad design and layout on dynamic behaviours, and on the relationships between dynamic and static behaviours. Finally, future studies should consider developing robust statistical models that use multiple features of campus quad design and layout to explain and predict students' static behaviours.

\section{References}

Abbas, M. \& Van Heur, B. (20I4). Thinking Arab women's spatiality: The case of 'mutanazahat'in Nablus, Palestine. Gender, Place \& Culture, 21, 1214-1229.

Abu-Ghazzeh, T. M. (1999). Communicating behavioral research to campus design factors affecting the perception and use of outdoor spaces at the University of Jordan. Environment and Behavior, 31, 764-804.

Abu-Obeid, N. \& Al-Homoud, M. (2000). Sense of privacy and territoriality as a function of spatial layout in university public spaces. Architectural Science Review, 43, 21 I-220.

Al-Bishawi, M. A. \& Ghadban, S. S. (20II). A methodological approach for reading urban open space. ArchNet-IJAR, International Journal of Architectural Research, 5, 73-85.

Al-Homoud, M. \& Abu-Obeid, N. (2003). University outdoor spatial layout effect on perception of students' interaction and group seclusion. Journal of Architectural and Planning Research, 20, $221-233$.

Aljawabra, F. \& Nikolopoulou, M. (2010). Influence of hot arid climate on the use of outdoor urban spaces and thermal comfort: Do cultural and social backgrounds matter? Intelligent Buildings International, 2, 198-217.

Aydin, D. \& Ter, U. (2008). Outdoor space quality: Case study of a university campus plaza. ArchNet-IJAR, International Journal of Architectural Research, 2, I89-2.

Bada, Y. \& Farhi, A. (2009). Experiencing urban spaces: Isovists properties and spatial use of Plazas. Courrier du Savoir, 9, 10I-II2.

Campos, M. B. (1997). All that meets the eye: Overlapping isovists as a tool for understanding preferable location of static people in public squares. First International Space Syntax Symposium, University College London, London. 0I.I-0I.9.

Ding, Y. \& Guaralda, M. (20I3). The study of design elements and people's behaviour in campus public space: how design shapes user's behaviour. In Bo: Ricerche e progetti per il territorio, la cittá e l'architettura, 4, I|4-136.

Evans, J. D. (1996). Straightforward Statistics for the Behavioral Sciences, Pacific Grove, CA, Brooks/Cole Publishing.

Francis, M. (2003). Urban Open Space: Designing for User Needs, Washington, DC, Island Press. 
Galindo, M. P. G. \& Corraliza, J. A. (2000). Environmental aesthetics and psychological wellbeing: Relationships between preference judgements for urban landscapes and other relevant affective responses. Psychology in Spain, 13-27.

Gehl, J. (20I I). Life Between Buildings: Using Public Space, Washington, DC, Island Press.

Ghavampour, E., Vale, B. \& Del Aguila, M. (2015). Nature as a Design Element in Small Urban Public Spaces. Future of Places. Stockholm.

Greene, M. \& Penn, A. (1997). Socio-spatial analysis of four University Campuses: the implications of spatial configuration on creation and transmission of knowledge. First International Space Syntax Symposium, London. University College London, I3.I-I3.16.

Herzog, T. R., Maguire, P. \& Nebel, M. B. (2003). Assessing the restorative components of environments. Journal of Environmental Psychology, 23, 159-170.

Hillier, B. \& Hanson, J. (1984). The Social Logic of Space Cambridge, Cambridge University Press.

IBM 2013. SPSS Statistics for Windows. 22 ed. Armonk, NY: IBM Corp.

Kaplan, R. \& Kaplan, S. (1989). The Experience of Nature: A Psychological Perspective, Cambridge, Cambridge University Press.

Lau, S. S. Y., Gou, Z. \& Liu, Y. (20I4). Healthy campus by open space design: Approaches and guidelines. Frontiers of Architectural Research, 3, 452-467.

Lo, S. M., Yiu, C. Y. \& Lo, A. (2003). An analysis of attributes affecting urban open space design and their environmental implications. Management of Environmental Quality: An International Journal, I4, 604-6I4.

Mcfarland, A., Waliczek, T. \& Zajicek, J. (2008). The relationship between student use of campus green spaces and perceptions of quality of life. HortTechnology, 18, 232-238.

Ministry Of Planning And International Cooperation Of The Kingdom Of Jordan \& United Nations Development Program (2004). Jordan human development report. Amman, Jordan.

Mozingo, L. (1989). Women and downtown open spaces. Places, 6, 38-47.

Peponis, J., Ross, C. \& Rashid, M. (1997). The structure of urban space, movement and copresence: The case of Atlanta. Geoforum, 28, 34I-358.

Rached, I. \& Elsharkawy, H. (20I2). The role of open spaces in the university campus in the Egyptian context. Designing Place - International Urban Design Conference, 2-3 April, Nottingham, UK. I-I5.

Rashid, M., Kampschroer, K., Wineman, J. \& Zimring, C. (2006). Spatial layout and face-to-face interaction in offices-a study of the mechanisms of spatial effects on face-to-face interaction. Environment and Planning B: Planning and Design, 33, 825-844.

Rashid, M., Wineman, J. \& Zimring, C. (2009). Space, behavior, and environmental perception in open-plan offices: a prospective study. Environment and Planning B: Planning and Design, 36, 432-449.

Reininger, M. K. (2004). Gender and space in Jordan: Boundaries and power in a Middle Eastern society. MA in Political Science, Virginia Polytechnic Institute and State University.

Salama, A. M. (2008). When good design intentions do not meet users expectations: Exploring Qatar University campus outdoor spaces. Archnet-IIAR, International Journal of Architectural Research, 2, 57-77.

Shi, S., Gou, Z. \& Chen, L. H. (20I4). How does enclosure influence environmental preferences? A cognitive study on urban public open spaces in Hong Kong. Sustainable Cities and Society, I3, I48-156.

Stamps, A. E. (2005). Enclosure and safety in urbanscapes. Environment and Behavior, 37, I02-1 33.

Stamps, A. E. \& Smith, S. (2002). Environmental enclosure in urban settings. Environment and Behavior, 34, 78I-794.

Turner, A., Doxa, M., O'sullivan, D. \& Penn, A. (200I). From isovists to visibility graphs: A methodology for the analysis of architectural space. Environment and Planning B: Planning and Design, 28, 103-121. 
Turner, A. \& Friedrich, E. (2000-20 I I). UCL Depthmap: Spatial Network Analysis Software. 10.14. 00b ed. London: University College London.

Ulrich, R. S. (1986). Human responses to vegetation and landscapes. Landscape and Urban Planning, I3, 29-44.

Unlu, A., Edgu, E., Cimsit, F., Salgamcioglu, M., Garip, E. \& Mansouri, A. (2009). Interface of indoor-outdoor spaces in buildings: A syntactic comparison of architectural schools in Istanbul. In: KOCH, D., MARCUS, L. \& STEEN, J., eds. Seventh International Space Syntax Symposium, Stockholm. KTH.

Unlu, A., Ozener, O. O., Ozden, T. \& Edgu, E. (200I). An evaluation of social interactive spaces in a university building. Third International Space Syntax Symposium, Atlanta. University of Michigan, 7-II.

Whyte, W. H. (1980). The Social Life of Small Urban Spaces, Washington DC, Conservation Foundation.

Woolley, H. (2003). Urban Open Spaces, New York, NY, Taylor \& Francis.

Yaylali-Yildiz, B., Czerkauer-Yamu, C. \& Çil, E. (20I4). Exploring the effects of spatial and social segregation in university campuses, IZTECH as a case study. Urban Design International, 19, I25-I 43. 